\title{
PENGEMBANGAN MODUL IPA BERBASIS INTEGRASI ISLAM DAN SAINS UNTUK MENINGKATKAN HASIL BELAJAR SISWA KELAS VI MIN 2 MOJOKERTO
}

\author{
Benny Angga Permadi ${ }^{1}$, Nur Syafi'ah Khotim ${ }^{2}$ \\ ${ }^{12}$ Dosen Institut Pesantren KH. Abdul Chalim Mojokerto \\ Email: bennyangga68@gmail.com ${ }^{1}$, nursyafiah27@gmail.com²
}

\begin{abstract}
The Development of IP A Module based on Islamic and scientific integration to Increase the Result Study of the Students in the sixth class in MIN 2 Mojokerto. This development of IP A module based on Islamic and scientific integration in MIN 2 Mojokerto is based on gaps include; first, the IPA result studies of the sixth class students in MIN 2 shows that 30\% students have not reach KKM score which is established 70; second, the IP A teaching material which is used has not an interesting design and the concept based on Islamic and scientific integration; third, there is not a teaching material which guides the students to get IP A concept as a medium for them to increase their beliefs toward Allah SWT. According to the research problem which is explained before, so the development of IP A module based on Islamic and scientific integration becomes an important thing to do. This development is to produce the development of IPA module based on Islamic and scientific integration; to know the specification, the use of, the effectiveness, and the interesting thing of IPA module based on Islamic and scientific integration in MIN 2 Mojokerto. The development of this module uses ADDIE (Analysis, Design, Development, Implementation, dan Evaluation) development model. These subject assessments for feasibility module are material expert, design expert, linguist, learning expert, and also the sixth class students in MIN 2 Mojokerto. The principal ways of this research are initial conditions analysis, the development of planning module, writing module, and assessment module. The collecting data which are used include questionnaires, interview, and the result of studies.
\end{abstract}

Keywords: Module, Islamic and scientific integration, the result of study.

Keywords: development of teaching materials, islamic integrity, result study

Nazhruna: Jurnal Pendidikan Islam

Vol. 1 No 2 Agustus 2018. Issn: 2614-8013. Hal. 294-311 


\begin{abstract}
Abstrak
Pengembangan Modul IPA berdasarkan integrasi Islam dan Ilmiah untuk Meningkatkan Hasil Belajar Siswa di kelas keenam di MIN 2 Mojokerto. Pengembangan modul IPA berdasarkan integrasi Islam dan ilmiah di MIN 2 Mojokerto didasarkan pada kesenjangan antara lain; pertama, hasil studi IPA siswa kelas enam di MIN 2 menunjukkan bahwa 30\% siswa belum mencapai skor KKM yang ditetapkan 70; kedua, materi ajar IPA yang digunakan tidak memiliki desain yang menarik dan konsep yang didasarkan pada integrasi Islam dan ilmiah; ketiga, tidak ada bahan ajar yang membimbing siswa untuk mendapatkan konsep IPA sebagai media bagi mereka untuk meningkatkan kepercayaan mereka kepada Allah SWT. Sesuai dengan masalah penelitian yang telah dijelaskan sebelumnya, maka pengembangan modul IPA berdasarkan integrasi Islam dan keilmuan menjadi hal yang penting untuk dilakukan. Pengembangan ini adalah untuk menghasilkan pengembangan modul IPA berdasarkan integrasi Islam dan ilmiah; untuk mengetahui spesifikasi, penggunaan, efektivitas, dan hal yang menarik dari modul IPA berdasarkan integrasi Islam dan ilmiah di MIN 2 Mojokerto. Pengembangan modul ini menggunakan model pengembangan ADDIE (Analisis, Desain, Pengembangan, Implementasi, dan Evaluasi). Penilaian subjek untuk modul kelayakan ini adalah ahli materi, ahli desain, ahli bahasa, ahli pembelajaran, dan juga siswa kelas enam di MIN 2 Mojokerto. Cara utama dari penelitian ini adalah analisis kondisi awal, pengembangan modul perencanaan, modul penulisan, dan modul penilaian. Pengumpulan data yang digunakan meliputi kuesioner, wawancara, dan hasil penelitian.
\end{abstract}

Kata kunci: Hasil belajar, Integrasi Islam, Pengembangan Bahan Ajar

\title{
Pendahuluan
}

Kurikulum 2013 merupakan kurikulum yang diterapkan mulai tahun ajaran 2013/2014 ini lebih menekankan pada pendidikan karakter, terutama pada tingkat pendidikan dasar, yang akan menjadi fondasi bagi tingkat pendidikan berikutnya, yakni pendidikan menengah umum, pendidikan menengah kejuruan dan pendidikan tinggi. Hal ini dimungkinkan, kalau implementasi kurikulum 2013 betul-betul dapat menghasilkan insan yang produktif, kreatif, dan berkarakter. Melalui kurikulum 2013, yang berbasis kompetensi sekaligus berbasis karakter, dengan pendekatan tematik integratif dalam implementasinya diharapkan siswa mampu secara mandiri meningkatkan dan menggunakan pengetahuannya, mengkaji, menginternalisasi dan 
mempersonalisasi nilai-nilai karakter serta akhlak mulia sehingga terwujud dalam perilaku sehari-hari ${ }^{1}$. Namun di sisi lain ada beberapa hal yang kurang dalam kurikulum 2013 yaitu kurangnya kesesuaian kompetensi pendidik dan tenaga kependidikan dengan kurikulum yang diajarkan dan buku teks yang dipergunakan, kurangnya kemampuan guru dalam mengimbangi perubahan kurikulum dan menyesuaikan dengan buku teks yang akan diajarkan pada peserta didik, dan kurangnya ketersediaan buku sebagai bahan ajar dan sumber belajar yang sesuai dengan model interaksi pembelajaran.

Dengan beberapa hal yang kurang dalam kurikulum 2013 maka dibutuhkan faktor pendukung untuk keberhasilan pelaksanaan kurikulum antara lain salah satunya adalah pengembangan bahan ajar dengan tujuan untuk mendukung keberhasilan proses belajar siswa. Bahan ajar merupakan bagian penting dalam pelaksanaan pendidikan. Melalui bahan ajar guru akan lebih mudah dalam melaksanakan pembelajaran dan siswa akan lebih terbantu dan mudah dalam belajar. ${ }^{2}$ Menurut Belawati ${ }^{3}$, bahan ajar dikelompokaan tiga macam yaitu bahan ajar cetak, noncetak, dan bahan ajar display. Jenis bahan ajar cetak yang dimaksud adalah modul, buku ajar, handout, dan lembar kerja siswa. Satu diantaranya modul yang merupakan bahan ajar yang menjadikan pembelajaran lebih efektif, efisien, dan relevan. ${ }^{4}$ Peran guru dalam pembelajaran dengan menggunakan modul adalah sebagai fasilitator, bukan lagi sebagai pihak yang mendominasi dalam pembelajaran, sehingga pembelajaran lebih berpusat pada siswa. ${ }^{5}$

Modul banyak digunakan dalam kegiatan pembelajaran. Satu diantaranya adalah modul IPA. Modul IPA bisa digunakan dalam menunjang pembelajaran IPA untuk mencapai tujuan pembelajaran. Dengan modul IPA dapat membimbing siswa untuk melakukan dan menemukan pengetahuan secara mandiri melalui kegiatan berupa percobaan, observasi maupun pendalaman konsep melalui paparan berbagai gambar. Selain itu modul juga memungkinkan siswa dapat mengukur atau mengevaluasi sendiri hasil belajarnya. ${ }^{6}$

${ }^{1}$ Mulyasa E, Pengembangan dan Implementasi Kurikulum 2013, hlm. 7

2 Mulyasa E, Pengembangan dan Implementasi Kurikulum 2013, hlm. 9

3 Jian Belawati, Pengembangan Bahan Ajar Edisi Kesatu, (Jakarta: Pusat Penerbitan Universitas Terbuka, 2003), hlm. 1

${ }^{4}$ M. Wena, Strategi Pembelajaran Inovatif Kontemporer: suatu tinjauan konseptual operasiona. (Jakarta: Bumi Aksara, 2014). hlm. 224

${ }^{5}$ Andi Prastowo, Pengembangan Sumber Belajar, (Yogyakarta: Pedagogia, 2012), hlm. 108

${ }^{6}$ Das Salirawati, Teknik Penyusunan Modul Pembelajaran, http://staff.uny.ac.id/dosen/dassalirawati-msi-dr, diakses tanggal 29 Juni 2016. 
IPA merupakan ilmu pengetahuan tentang gejala alam yang dituangkan dalam bentuk fakta, konsep, prinsip, dan hukum yang teruji kebenarannya. IPA memiliki dua dimensi yaitu dimensi produk dan dimensi proses. Akan tetapi terdapat beberapa hal yang sering dilupakan oleh pendidik dalam mengajarkan IPA yakni menyampaikan IPA sebagai sebuah produk/ konsep dengan melupakan keterampilan proses (langkah ilmiah) di dalamnya, sehingga siswa belajar kurang bermakna. Pembelajaran bermakna ini sangat penting dalam pembelajaran IPA karena konsep-konsep yang dipelajari siswa di sekolah akan dapat digunakan siswa dalam memecahkan masalah yang mereka jumpai dalam kehidupan sehari-hari. ${ }^{7}$ Melalui modul IPA yang dikembangkan dalam penelitian ini dimensi proses lebih terakomodasi, sehingga peran siswa dapat mempelajari IPA tidak hanya dengan dimensi produk saja dan belajar lebih bermakna.

Manusia dalam kehidupan sehari-hari tidak pernah lepas dengan IPA dan produknya. Hal ini disebabkan karena kehidupan manusia sangat bergantung pada alam, zat yang terkandung di alam, dan segala jenis gejala yang terjadi di alam, jadi dapat dikatakan bahwa IPA dan produknya merupakan tulang punggung bagi manusia dalam menjalankan kehidupan yang bersifat duniawi.

Dengan demikian pembelajaran IPA di madrasah secara normatif, kedudukan IPA perlu dikawal dengan agama supaya tidak terjadi penyalahgunaan IPA sehingga IPA dapat mendatangkan kemaslahatan di dunia. Jadi pada dasarnya agama dan IPA tidak dapat berdiri sendiri, inilah yang dikenal sebagai konsep Integrasi Islam dan sains. Pentingnya integrasi Islam dan sains di kalangan muslim ini karena munculnya anggapan dalam masyarakat luas yang mengatakan bahwa agama dan sains adalah dua entitas yang tidak bisa dipertemukan yaitu keduanya mempunyai wilayah sendiri secara terpisah antara satu dengan lainnya. ${ }^{8}$

Berdasarkan fakta tersebut, menjadi penting sebagai pendidik untuk dapat mengintegrasikan antara Islam dan sains melalui pembelajaran dengan cara menanamkan keyakinan terhadap kekuasaan Allah SWT melalui pembelajaran IPA sejak dini. Materi IPA yang dikembangkan oleh peneliti adalah perkembangbiakan makhluk hidup, adaptasi, energi listrik dan penghematannya. ${ }^{9}$ Berdasarkan kurikulum 2013 pada kelas 6 SD/MI semester I

\footnotetext{
${ }^{7}$ Asih Widi Wisudawati dan Eka sulistyowati, Metodologi Pembelajaran IPA, (Jakarta: Bumi Aksara, 2015), hlm. 43-44.

${ }^{8}$ Rasmianto, Jurnal Studi Islam;Ulul albab Vol. 9 No. 1, (Malang: UIN Pers, 2008), hlm. 4.

${ }^{9}$ Priyono dan Titiek Sayekti, Ilmu Pengetabuan Alam untuk SD dan MI kelas VI, (Jakarta: Pusat Pembukuan, 2013) hlm. 12
} 
meliputi kompetensi dasar mendeskripsikan perkembangbiakan makhluk hidup, mengidentifikasi cara makhluk hidup menyesuaikan diri dengan lingkungan, mengidentifikasi sumber energi listrik dan rangkaian listrik sederhana, dan menjelaskan cara penghematan energi listrik.

Penelitian pengembangan bahan ajar ini dilakukan di MIN 2 Mojokerto. Hal ini dilandasi oleh pemikiran beberapa kondisi yang ditemukan berdasarkan wawancara dengan Guru MIN 2 Mojokerto. Pertama, hasil belajar IPA pada materi perkembangbiakan dan adaptasi siswa kelas VI di MIN 2 Mojokerto yang menunjukkan bahwa 30\% peserta didik belum mencapai nilai KKM yang telah ditetapkan yaitu 70 . Kedua, belum tersedianya bahan ajar berbasis integrasi Islam dan sains yang membimbing siswa dalam memperoleh konsep IPA sebagai bekal siswa dalam menambah keyakinan siswa terhadap Allah SWT. ${ }^{10}$

Mengingat keberadaan bahan ajar sangat penting, maka penelitian pengembangan ini ditujukan pada bahan ajar IPA yang sudah ada dan dipakai di Madrasah Ibtidaiyah yakni MIN 2 Mojokerto khususnya kelas VI memiliki kondisi kurang menarik dalam desain dan belum ditemukan konsep berbasis integrasi Islam dan sains. ${ }^{11}$ Sedangkan bahan ajar yang dikembangkan dalam bentuk modul IPA berbasis integrasi Islam dan sains ini diharapkan memiliki efektivitas dan kemenarikan yang berkaitan dengan hasil belajar siswa kelas VI MIN 2 Mojokerto.

Berdasarkan latar belakang masalah yang telah diuraikan, maka dirumuskan tujuan penelitian dan pengembangan antara lain untuk mengetahui spesifikasi n dpenggunaan modul IPA berbasis integrasi Islam dan sains, dan untuk mengetahui efektivitas dan kemenarikan modul IPA berbasis integrasi Islam dan sains pada materi semester I terhadap hasil belajar siswa kelas VI MIN 2 Mojokerto.

\section{Metode}

Pada penelitian pengembangan bahan ajar berupa modul pembelajaran IPA berbasis integrasi Islam dan sains pada materi semester I di Kelas VI MIN 2 Mojokerto, peneliti menggunakan model pengembangan deskriptif dengan model pengembangan ADDIE. Model pengembangan ADDIE terdiri dari lima tahap sesuai dengan namanya yang merupakan singkatan dari Analysis (Analisis),

\footnotetext{
${ }^{10}$ Wawancara dengan Bapak Purwandik, Guru Mata Pelajaran IPA Kelas VI MIN 2 Mojokerto

${ }^{11}$ Buku teks tersebut berjudul Tema 1 Selamatkan Makbluk Hidup (IPA) tematik kelas VI SD/MI (2013)
} 
Design (Desain), Development (Pengembangan), Implementation (Implementasi), dan Evaluation (Evaluasi).

Prosedur Penelitian dan Pengembangan

Prosedur pengembangan dalam penelitian pengembangan ini mengikuti langkah-langkah yang diintruksikan dalam model pengembangan ADDIE diantaranya sebagai berikut:

1. Analysis (analisis)

Tujuan analisis ini adalah untuk mendefinisikan secara jelas perincian program atau rancangan. Pada tahap ini peneliti menganalisis hal yang terkait dengan pengembangan bahan ajar antara lain : analisis kurikulum, analisis kebutuhan, dan analisis pengembangan bahan ajar.

2. Design (desain)

Sesudah tahap analisis, selanjutnya dirancang modul IPA berbasis integrasi Islam dan sains. Kegiatan yang dilakukan pada tahap perencanaan adalah :

a. Menyiapkan buku referensi yang berkaitan dengan materi perkembangbiakan makhluk hidup, penyesuaian diri makhluk hidup terhadap lingkungan, energi listrik dan penghematannya, dan buku referensi tentang ayat-ayat Al-Qur'an yang berkaitan dengan materi tersebut.

b. Menyusun peta kebutuhan modul.

c. Penyusunan desain modul.

d. Penyusunan Desain Instrumen Penilaian

3. Development (pengembangan)

Menurut Benny ${ }^{12}$, ada dua tujuan penting yang perlu dicapai dalam melakukan langkah pengembangan, yaitu : (a) memproduksi, membeli atau merevisi bahan ajar yang akan digunakan untuk mencapai tujuan pembelajaran yang telah dirumuskan sebelumnya, dan (b) memilih media atau kombinasi media yang akan digunakan untuk mencapai tujuan pembelajaran. Oleh karena itu kegiatan yang dilakukan pada tahap ini adalah :

a. Penulisan draft modul

b. Pengembangan instrumen penilaian dan angket respon siswa

c. Pengembangan soal tes

12 Benny A. Pribadi, Model Desain Sistem Pembelajaran, hlm. 133 
Nazhruna: Jurnal Pendidikan Islam
d. Validasi produk
e. Revisi

4. Implementation (pelaksanaan)

Modul IPA berbasis integrasi Islam dan sains yang telah divalidasi kemudian diujicobakan pada siswa. Untuk uji coba pada siswa terdapat tiga tahap yang akan diberikan uji kepada perorangan (one-on-one evaluation), uji kelompok kecil (small group evaluation), dan uji lapangan (field evaluation). Tahap ini akan menganalisis ketepatan perancangan atau desain pembelajaran, ketepatan isi bahan ajar, kemenarikan, dan keefektifan modul yang dikembangkan bagi siswa. Pada tahap ini akan diperoleh data nilai hasil tes yang mengukur keefektifan modul. Sedang hasil angket respon siswa dan guru digunakan untuk mengukur ketepatan perancangan atau desain pembelajaran, ketepatan isi bahan ajar serta kemenarikan modul dan bisa menjadi acuan untuk penyempurnaan modul.

5. Evaluation (evaluasi)

Evaluasi merupakan proses yang dilakukan untuk memberikan nilai terhadap produk. Pada tahap ini akan dilakukan kegiatan evaluasi tentang kualitas produk hasil pengembangan bahan ajar berdasarkan hasil angket respon guru dan siswa serta pendapat dari ahli. Sesudah dievaluasi, maka revisi akhir produk akan dilakukan akan menghasilkan hasil akhir yang layak pakai dalam pembelajaran.

\section{Desain Uji Coba}

Pengujian Modul Pembelajaran ini dilakukan dengan desain eksperimen pretest posttest one group design ${ }^{13}$. Desain penelitian menggunakan satu kelas yang menjadi sampel penelitian. Kelas eksperimen diberi perlakuan berupa pembelajaran menggunakan modul.

Subjek Uji Coba

Subjek uji coba dalam penelitian pengembangan modul pembelajaran IPA berbasis integrasi Islam dan sains ini terdiri atas:

1. Ahli Materi

Ahli materi yang ditetapkan sebagai penguji materi/ isi modul IPA berbasis integrasi Islam dan sains adalah Ibu Dr. Retno Susilowati, M.Si sebagai validator isi/materi berbasis integrasi Islam dan sains terkait materi

${ }^{13}$ Sugiyono, Metode Penelitian Pendidikan,hlm. 75 
materi perkembangbiakan makhluk hidup, penyesuaian makhluk hidup terhadap lingkungan, energi listrik dan penghematannya.

2. Ahli Desain Pembelajaran

Ahli desain yang ditetapkan sebagai penguji desain/media pembelajaran dalam hal ini modul IPA berbasis integrasi Islam dan sains ini adalah Bapak Dr. Muhammad Walid, M.A.

3. Ahli Bahasa

Ahli bahasa yang ditetapkan sebagai penguji bahasa pembelajaran dalam hal ini modul IPA berbasis integrasi Islam dan sains ini adalah Dr. Titik Harsiati, M.Pd dosen bahasa Indonesia di Universitas Negeri Malang.

4. Ahli Praktisi Pembelajaran IPA MIN 2 Mojokerto

Ahli praktisi pembelajaran yang memberikan tanggapan dan penilaian terhadap modul pembelajaran ini adalah guru kelas VI yang sehari-hari mengajar IPA di MIN 2 Mojokerto. Adapun guru mata pelajaran IPA di MIN 2 Mojokerto adalah Bapak Purwandik, S.Pd.I.

5. Siswa Kelas VI MIN 2 Mojokerto

Uji coba lapangan dilakukan pada semester I tahun ajaran 2017/ 2018. Subjek uji coba lapangan ini adalah siswa kelas VIA MIN 2 yang keseluruhan berjumlah 27 siswa.

Jenis Data

Terdapat dua jenis data yang diperlukan untuk produk yang dikembangkan dan tujuan pembelajaran dalam penelitian pengembangan ini. Kedua jenis data tersebut berupa data kuantitatif dan data kualitatif yang digunakan sebagai acuan untuk menentukan keefektifan, efesisensi dan kemenarikan produk yang dihasilkan.

Instrument Pengumpulan Data

Berdasarkan jenis data yang telah dipaparkan diatas, dalam penelitian pengembangan ini terdapat beberapa instrument pengumpulan data yang dibutuhkan peneliti untuk mendunkung penelitian diantaranya adalah angket, wawancara, dan tes hasil belajar.

\section{HASIL PENGEMBANGAN}

1. Spesifikasi Modul IPA Berbasis Integrasi Islam dan Sains

Pengembangan bahan ajar yang dihasilkan dari penelitian pengembangan ini berupa "modul IPA berbasis integrasi Islam dan sains 
pada materi perkembangbiakan, adaptasi, energi listrik dan penghematannya".

Modul ini memiliki beberapa spesifikasi sebagai berikut:

a. Wujud fisik dari produk yang dihasilkan dalam pengembangan ini adalah media cetak berupa modul (material printed)

b. Modul ini dikembangkan dengan menggunakan Dalil-dalil yang ada bersumber dari Al-Qur'an yang di terbitkan oleh Kementrian Agama RI.

c. Hasil belajar yang sesuai dengan pembelajaran dengan menggunakan modul ini ditujukan untuk mencapai KI, KD yang ada dalam kurikulum 2013 dan sebagai sarana siswa dalam menambah keyakinan terhadap Allah SWT melalui integrasi dengan dalil Al-Qur'an.

d. Bentuk fisik modul dalam pengembangan ini berupa media cetak yang disusun dengan menggunakan variasi tata letak, pilihan warna, variasi huruf yang sesuai dengan ketentuan penulisan bahan ajar menurut Badan Standar Nasional Pendidikan (BSNP) agar sesuai dengan karakter peserta didik, sehingga modul ini menjadi menarik untuk dijadikan bahan ajar.

e. Pada Modul terdapat kegiatan untuk siswa berupa kegiatan percobaan dan latihan dalam mempelajari konsep IPA sehingga siswa dapat belajar IPA melalui dimensi proses dan produk.

2. Efektivitas dan Kemenarikan Modul IPA Berbasis Integrasi Islam dan Sains terhadap Hasil Belajar

Pada efektivitas dan kemenarikan modul IPA berbasis integrasi Islam dan sains akan dipaparkan sembilan data yang berkaitan dengan hasil pengembangan. Adapun sembilan data tersebut yaitu: (a) Validasi Ahli Materi, (b) Validasi Ahli Desain/media Pembelajaran, (c) Validasi Ahli Bahasa, (d) Validasi Ahli Praktisi Pembelajaran/guru IPA kelas VI, (e) Uji Coba Perorangan, (f) Uji Coba Kelompok Kecil, (g) Uji Coba Lapangan, (h) Hasil Hasil Pre-Test dan Post-Test, dan (i) Analisis Efektivitas dan Kemenarikan Modul IPA Berbasis Integrasi Islam dan Sains.

a. Validasi Ahli Materi

Berdasarkan hasil penilaian ahli materi/isi pembelajaran terhadap modul IPA berbasis integrasi Islam dan sains menunjukkan persentase tingkat pencapaian $86 \%$ berada pada tingkat kualifikasi valid sehingga modul IPA berbasis integrasi Islam dan sains tidak perlu direvisi.

b. Validasi Ahli Desain/Media Pembelajaran 
Berdasarkan hasil penilaian ahli desain/media pembelajaran terhadap modul IPA berbasis integrasi Islam dan sains menunjukkan tingkat pencapaian $86 \%$ berada pada tingkat kualifikasi valid sehingga modul IPA berbasis integrasi Islam dan sains tidak perlu direvisi.

c. Validasi Ahli Bahasa

Berdasarkan hasil penilaian ahli bahasa terhadap modul IPA berbasis integrasi Islam dan sains menunjukkan persentase tingkat pencapaian $78 \%$ berada pada tingkat kualifikasi cukup valid sehingga modul IPA berbasis integrasi Islam dan sains tidak perlu direvisi.

d. Validasi Ahli Praktisi Pembelajaran IPA Kelas VI

Berdasarkan hasil penilaian ahli praktisi pembelajaran IPA kelas VI terhadap modul IPA berbasis integrasi Islam dan sains menunjukkan persentase tingkat pencapaian 94\% berada pada tingkat kualifikasi valid sehingga modul IPA berbasis integrasi Islam dan sains tidak perlu direvisi.

e. Uji coba perorangan (one on one)

Produk pengembangan diuji cobakan secara perorangan yang diwakili oleh 3 responden yaitu satu anak mewakili siswa berkemampuan baik, satu anak berkemampuan sedang/menengah, dan satu anak yang berkemampuan rendah.

Berdasarkan hasil uji coba perorangan (one on one) terhadap modul IPA berbasis integrasi Islam dan sains menunjukkan persentase tingkat pencapaian $84 \%$ berada pada tingkat kriteria sangat menarik sehingga modul IPA berbasis integrasi Islam dan sains tidak perlu direvisi.

f. Uji Coba Kelompok Kecil (Small Group Evaluation)

Produk pengembangan ini selanjutnya diuji cobakan pada kelompok kecil (Small Group Evaluation) yang diwakili oleh 6 responden yaitu dua anak mewakili siswa berkemampuan baik, dua anak berkemampuan sedang/ menengah, dan dua anak yang berkemampuan rendah.

Berdasarkan hasil uji kelompok kecil (small group evaluation) terhadap modul IPA berbasis integrasi Islam dan sains menunjukkan persentase tingkat pencapaian $87 \%$ berada pada tingkat kriteria sangat menarik sehingga modul IPA berbasis integrasi Islam dan sains tidak perlu direvisi.

g. Uji Lapangan (Field Evaluation) 
Uji coba lapangan dilakukan pada seluruh siswa di kelas eksperimen yaitu kelas VI A yang berjumlah 27 anak.

Berdasarkan hasil uji lapangan (field evaluation) terhadap modul IPA berbasis integrasi Islam dan sains menunjukkan persentase tingkat pencapaian $87 \%$ berada pada tingkat kriteria sangat menarik sehingga modul IPA berbasis integrasi Islam dan sains tidak perlu direvisi.

h. Hasil Pre-Test dan Post-Test

Produk pengembangan diujikan kepada siswa kelas VI MIN 2 Mojokerto dilakukan di kelas VIA sebagai kelas Eksperimen yang diberi perlakuan yaitu menggunakan modul IPA berbasis integrasi Islam dan sains. Peneliti mengambil kelas yang berjumlah 27 siswa di kelas eksperimen.

Hasil nilai yang diperoleh, secara spesifik akan dijabarkan pada grafik perbandingan perolehan nilai pre-test dan post-test kelas VIA (eksperimen) berikut ini:

\section{Grafik Nilai Pre-Test dan Post-Test Kelas VIA MIN 2}

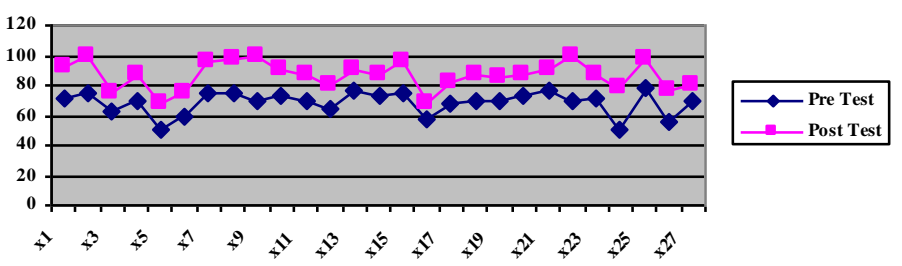

Berdasarkan

data hasil pre-test dan post-test kelas VIA (eksperimen) yang telah dipaparkan, selanjutnya dianalisis tingkat efektivitas penggunaan modul IPA berbasis integrasi Islam dan sains dengan melakukan beberapa tahap analisis sebagai berkut:

1) Analisis Tahap Awal

Rata-rata hitung (Mean)

Berdasarkan hasil belajar, selanjutnya dianalisis rata-rata hitung hasil belajar pre-test 68,48 dan post test 86,63 kelas eksperimen. Ragam/varians

Berdasarkan hasil belajar pada tabel rata-rata, kemudian dijadikan data sebagai analisis varians pada kelompok eksperimen untuk dijadikan teknik untuk mengetahui homogenitas kelompok, 
berikut ini merupakan ragam/varians hasil belajar pre-test 59,13 dan post test 90,25 pada kelompok eksperimen

2) Analisis Tahap Akhir

Setelah data hasil test dianalisis dengan menlakukan uji normalitas dilanjutkan dengan uji hipotesis. Uji hipotesis untuk mengetahui manakah yang lebih efektif antara "modul pembelajaran IPA berbasis integrasi Islam dan sains" dengan "bahan ajar konvensional", untuk menguji hipotesis dalam penelitian dengan analisis menggunakan independent sample t test sebagai berikut:

$\mathrm{H}_{\mathrm{o}}$ : tidak ada perbedaan hasil belajar IPA yang signifikan antara siswa kelas VI sesudah menggunakan modul IPA berbasis A integrasi Islam dan sains (post-test) dengan kelas VI sebelum menggunakan modul IPA berbasis integrasi Islam dan sains (pre-test).

$\mathrm{H}_{\mathrm{a}}$ : ada perbedaan hasil belajar IPA yang signifikan antara siswa kelas VI sesudah menggunakan modul IPA berbasis integrasi Islam dan sains (post-test) dengan kelas VI sebelum menggunakan modul IPA berbasis integrasi Islam dan sains (pre-test).

Berdasarkan hasil perhitungan diperoleh $t_{\text {hitung }}=9,02$ dan $t_{\text {tabel }}=$ 1,684 Karena $t_{\text {hitung }}>t_{\text {tabel }}$ maka $\mathrm{H}_{\mathrm{o}}$ ditolak dan $\mathrm{H}_{\mathrm{a}}$ diterima. Ini berarti ada perbedaan hasil belajar IPA siswa kelas VIA yang signifikan antara sesudah menggunakan modul IPA berbasis integrasi Islam dan sains dengan sebelum menggunakan modul IPA berbasis integrasi Islam dan sains. Jadi dapat disimpulkan bahwa, modul IPA berbasis integrasi Islam dan sains yang dikembangkan terbukti secara signifikan efektif untuk meningkatkan hasil belajar siswa.

i. Analisis Efektivitas dan Kemanarikan Modul IPA Berbasis Integrasi Islam dan Sains

Efektivitas modul IPA berbasis integrasi Islam dan sains terhadap hasil belajar berdasarkan uji coba lapangan yang diukur menggunakan tes pencapaian hasil belajar setelah dianalisis menunjukkan:

1) Rata-rata perolehan hasil belajar pada kelas VIA mengalami peningkatan dari perolehan nilai awal 68,48 meingkat menjadi 86,63 .

2) Tingkat efektivitas penggunaan modul dianalisis dengan menggunakan independent sample t-test untuk menguji hipotesis. Berdasarkan hasil perhitungan diperoleh $t_{\text {hitung }}=9,02$ dan $t_{\text {tabel }}=$ 
1,684 Karena $t_{\text {hitung }}>t_{\text {tabel }}$ maka $H_{o}$ ditolak dan $H_{a}$ diterima. Jadi dapat disimpulkan bahwa, modul IPA berbasis integrasi Islam dan sains yang dikembangkan terbukti secara signifikan efektif untuk meningkatkan hasil belajar siswa.

Kemenarikan modul IPA berbasis integrasi Islam dan sains memiliki tingkat kemenarikan yang tinggi berdasarkan uji coba lapangan yang diukur menggunakan tanggapan penialain semua siswa kelas VIA MIN 2 Mojokerto menunjukkan persentase penilaian siswa terhadap semua komponen mencapai $87 \%$ dengan kriteria sangat menarik.

\section{Penutup}

Kesimpulan Hasil Pengembangan

Berdasarkan proses pengembangan dari hasil uji coba modul IPA berbasis integrasi Islam dan sains, dapat diuraikan beberapa kesimpulan, diantaranya :

a. Spesifikasi modul IPA berbasis integrasi Islam dan sains berupa media cetak (materianl printed). Modul ini dikembangkan dengan menggunakan Dalil-dalil yang ada bersumber dari Al-Qur'an yang diterbitkan oleh Kementrian Agama RI. Hasil belajar yang sesuai dengan pembelajaran dengan menggunakan modul ini ditujukan untuk mencapai KI, KD yang ada dalam kurikulum 2013 dan sebagai sarana siswa dalam menambah keyakinan terhadap Allah SWT melalui integrasi dengan dalil Al-Qur'an. Bentuk fisik modul dalam pengembangan ini berupa media cetak yang disusun dengan menggunakan variasi tata letak, pilihan warna, variasi huruf yang sesuai dengan ketentuan penulisan bahan ajar menurut Badan Standar Nasional Pendidikan (BSNP). Pada Modul terdapat kegiatan untuk siswa berupa kegiatan percobaan dan latihan dalam mempelajari konsep IPA sehingga siswa dapat belajar IPA melalui dimensi proses dan produk.

b. Efektivitas dan kemenarikan modul IPA berbasis integrasi Islam dan sains terhadap hasil belajar siswa kelas VI MIN 2 Mojokerto.

1) Hasil penelitian menunjukkan bahwa modul IPA berbasis integrasi Islam dan sains memiliki tingkat kevalidan materi $87 \%$ (valid), kevalidan desain $86 \%$ (valid), kevalidan bahasa 78\% (cukup valid), dan kevalidan pembelajaran $94 \%$ (valid). 
2) Efektivitas modul IPA berbasis integrasi Islam dan sains terhadap hasil belajar berdasarkan uji coba lapangan yang diukur menggunakan tes pencapaian hasil belajar setelah dianalisis menunjukkan:

a) Rata-rata perolehan hasil belajar pada kelas VIA MIN 2 Mojokerto mengalami peningkatan dari perolehan nilai awal 68,48 meingkat menjadi 86,63.

b) Tingkat efektivitas penggunaan modul dianalisis dengan menggunakan independent sample t-test untuk menguji hipotesis. Berdasarkan hasil perhitungan diperoleh $t_{\text {hitung }}=9,02$ dan $t_{\text {tabel }}=1,684$ Karena $t_{\text {hitung }}>t_{\text {tabel }}$ maka $\mathrm{H}_{\mathrm{o}}$ ditolak dan $\mathrm{H}_{\mathrm{a}}$ diterima. Jadi dapat disimpulkan bahwa, modul IPA berbasis integrasi Islam dan sains yang dikembangkan terbukti secara signifikan efektif untuk meningkatkan hasil belajar siswa.

3) Tingkat kemenarikan modul IPA berbasis integrasi Islam dan sains memiliki tingkat kemenarikan yang tinggi berdasarkan uji coba lapangan yang diukur menggunakan tanggapan penialain semua siswa kelas VIA MIN 2 Mojokerto menunjukkan persentase penilaian siswa terhadap semua komponen mencapai $87 \%$ dengan kriteria sangat menarik.

\section{Daftar Rujukan}

Arikunto, Suharsimi, Dasar-Dasar Evaluasi Pendidikan, Jakarta: Bumi Aksara, 2003.

Arthur dan Roberts, Pendidikan Fisika, Jakarta: UPI, 2003.

Ary, Donald, Dkk. Introduction to research in education, Terj. Arif Furqon, Surabaya: Usaha Nasional, 1982.

Belawati, Jian, Pengembangan Bahan Ajar Edisi Kesatu, Jakarta: Pusat Penerbitan Universitas Terbuka, 2003.

Campbell, N.A.; J.B. Reece; L.G. Mitchell. Biologi Jilid 1 (Edisi Kedelapan). Penerjemah: Damaring Tyas Wulandari, Jakarta: Penerbit Erlangga, 2010.

Daryanto, Menyusun Modul, Yogyakarta: Gava Media, 2013. 
Nazhruna: Jurnal Pendidikan Islam

Depdiknas Ditjen Manajemen Dikdasmen Ditjen Pembinaan TK dan SD, 2007.

Dunne, Richard, Pembelajaran Efektif (Terjemahan), Jakarta: Grasindo, 1996.

Fardiana, Uun, Pengembangan Media Pembelajaran IP A berbasis Al-Qur'an pada kelas IV Tabun 2014 Mamba'ul Huda Ngabar Ponorogo, Tesis M.Pd. Jogyakarta: P.PS. UIN Sunan Kalijogo, 2014.

Gulo, W, Metodologi Penelitian, Jakarta: PT. Grasindo, 2007.

Hakim, Fachri, Endang Susila Ningsih, dan Edy Cahyono, Pengembangan Modul Kimia Terintegrasi Karakter Islami Pada Materi Reaksi Redoks di MAN 1 Kudus, Semarang:Journal of Innovative Science Education, 2015.

Iskandar, Penelitian Tindakan Kelas, Jakarta: Gaung Persada Press, 2009.

Kementrian Agama RI, Tafsir Ilmi Penciptaan Bumi dalam Perspektif al-Qur'an dan Sains, Jakarta :Kementrian Agama RI, 2012.

Kimball, J.W., Biologi Jilid 1 (Edisi 5). Penerjemah: Siti Soetarmi T dan Nawangsari Sugiri, Jakarta: Penerbit Erlangga, 1986.

Majid, Abdul, Perencanaan Pembelajaran, Bandung: PT. Remaja Rosda Karya, 2007.

Mardapi, Djemari, Teknik Penyusunan Instrumen, Yogyakarta: Mitra Cendikia, 2008.

Mudlofir, Ali, Aplikasi Pengembangan Kurikulum Satuan Pendidikan dan Bahan Ajar dalam Pendidikan Agama Islam, Jakarta: Rajawali Pers, 2011.

Mulyasa E, Pengembangan dan Implementasi Kurikulum 2013, Bandung: PT Remaja Posdakarya, 2013.

Muhaimin, Pengembangan Kurikulum Pendidikan Agama Islam di Sekolah, Madrasah, dan Perguruan Tinggi, Jakarta: PT. Grafindo Persada, 2005. 
Muslich, Masnur, Text Book Writing, Jogjakarta: Ar-Ruzz Media, 2010.

Nata, Abuddin, dkk., Integrasi Ilmu Agama dan Ilmu Umum, Jakarta: PT. Grafindo Persada, 2005.

Najati, Utsman al-Qur'an wa 'ilmu al-Nafs, terj. Ahmad Rofi' 'usman, Cet I; Bandung: Pustaka, 1985.

Nurgiyantoro, Burhan, Penilaian dalam Pengajaran Bahasa dan Sastra, Yogyakarta: BPFE, 2001.

Popham, W. James , Teknik Mengajar Secara Sistematis (Terjemahan), Jakarta: Rineka cipta, 2003.

Prastowo, Andi, Panduan Kreatif Membuat Bahan Ajar Inovatif, Yogyakarta: Diva Press, 2012.

Pribadi, Benny A, Model Desain Sistem Pembelajaran, Jakarta: Dian Rakyat, 2009.

Priyono dan Titiek Sayekti, Ilmu Pengetabuan Alam untuk SD dan MI kelas VI, Jakarta: Pusat Perbukuan,Departemen Pendidikan Nasional, 2008.

Puspitarini, Margaret, Kelebihan dan Kekurangan Kurikulum 2013, http://news.okezone.com/read/2014/11/08/65/1062782/kelebihankekurangan-kurikulum-2013, diakses tanggal 29 Juni 2016.

Salirawati, Das, Teknik Penyusunan Modul Pembelajaran, http://staff.uny.ac.id/dosen/das-salirawati-msi-dr, diakses tanggal 29 Januari 2016.

Sanjaya, Wina, Penelitian Tindakan Kelas, Jakarta: Kencana Prenada Media Group, 2009.

Saprun, Pengembangan Bahan Ajar Pembelajaran Baca Al-Qur'an Berbasis Otak kiri untuk orang dewasa di Universitas Muhamadiyah Mataram, Thesis M.Pd. Malang: P.PS. UIN Maulana Malik Ibrahim, 2012. 
Nazhruna: Jurnal Pendidikan Islam

Setyosari, Punaji, Metode Penelitian Pendidikan dan Pengembangan, Jakarta: Kencana, 2010.

Shihab, M. Quraish, Tafsir Al-Misbah Pesan, Kesan, dan Keserasian al-Qur'an, Jakarta: Penerbit Lentera Hati, 2011.

Shihab, M. Quraish, Membumikan Al-Qur'an, Fungsi Dan Peran Wabyu, Dalam Kehidupan Masyarakat, Bandung: Mizan, 1994.

Silviana, Pengembangan Modul Berbasis Integrasi Islam dan Sains Dengan Pendekatan Inkuiri di MI Salafiyah Kutukan Blora, Tesis M.Pd. Malang: P.PS. UIN Maulana Malik Ibrahim, 2016.

Starr, Cecie; Ralph Taggart; Christine Evers; Lisa Starr, Biologi Kesatuan dan Keragaman Makbluk Hidup Buku 1 (Edisi 12). Penerjemah: Yenny Prasaja, Jakarta: Penerbit Salemba Teknika, 2012.

Sudjana, Metode Statistika, Bandung: Tarsito, 2005.

Sugiyono, Metode Penelitian Pendidikan, Bandung: Alfabeta, 2009.

Sugiyono, Metode Penelitian Pendidikan Pendekatan Kuantitatif, Kualitatif, dan R \& D, Bandung: Alfabeta, 2013.

Sugiyono, Statistik untuk Penelitian, Bandung, Alfabeta, 2010.

Sukmadinata, Nana Syaodih, Metode Penelitian Pendidikan. Bandung: PT. Remaja Rosdakarya, 2007.

Suprayogo, Imam, Paradigma Pengembangan Keilmuan Islam Perspektif UIN Malang, (Malang : UIN-Malang Press, 2006.

Soemarwoto, Idjah; Indrawati Gandjar.; Edi Guhardja.; Andi Hakim Nasoetion.; Sri Sabanni Soemartono.; Lili Koeshartini Somadikarta, Biologi Umum III, .Jakarta: Gramedia Pustaka Utama, 1990. 
Syafi'ie, Imam, Konsep Ilmu Pengetabuan dalam al-Qur'an, Yogyakarta: UII Pers, 2000.

Syamsul, Ciri-ciri Makbluk Hidup, http://www.ilmupengetahuanalam. com/2016/02/pengertian-ciri-ciri-makhluk-hidup-besertacontohnya.html, diakses tanggal 29 Juni 2016.

Utomo, Tjipto, Peningkatan dan Pengembangan Pendidikan, Jakarta: Gramedia Pustaka Utama, 1991.

Wibowo, Teguh, dkk., Pengembangan Bahan Ajar Termodinamika dengan Pendekatan Terpadu Pendidikan Karakter untuk Meningkatkan Logika Siswa, ((Surabaya: Journal of Innovative Science Education, 2015), Vol 4, No 1.

Widoyoko, Eko Putro, Teknik Penyusunan Instrumen Penelitian, Yogyakarta: Pustaka Pelajar, 2012.

Wisudawati, Asih Widi dan Eka Sulistyowati, Metodologi Pembelajaran IPA, Jakarta: Bumi Aksara, 2015.

Wonohardjo, Surjani, Dasar-dasar Sains, Jakarta: Indeks, 2010. 